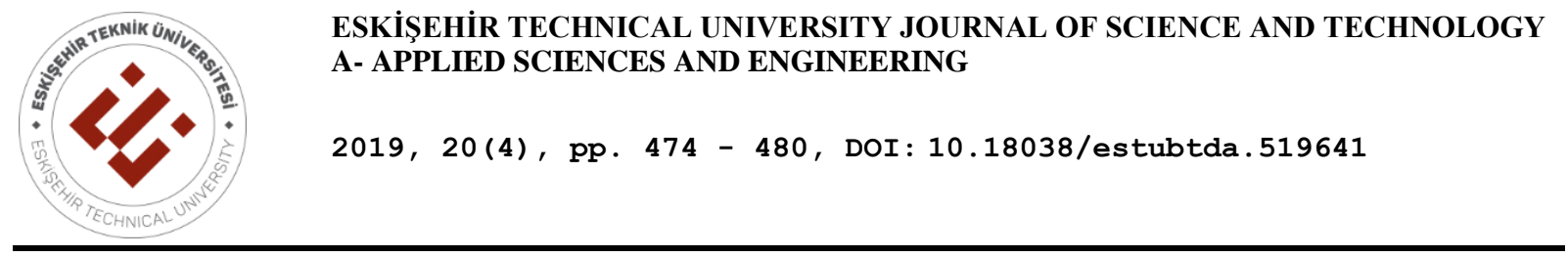

\title{
THE ANALYSES OF THE EFFECT OF HEAT TREATMENT ON THE STRUCTURAL PROPERTIES OF ZEOLITES FROM TURKEY USING FT-IR, MAS NMR AND XRD METHODS
}

\author{
Burcu ERDOĞAN ${ }^{1}$, Gökhan DİKMEN², Özgür ALVER ${ }^{1, *}$ \\ ${ }^{1}$ Department of Physics, Science Faculty, Eskişehir Technical University, Eskişehir, Turkey \\ ${ }^{2}$ Central Research Laboratory, Eskişehir Osmangazi University, Eskişehir, Turkey
}

\begin{abstract}
Upon the heat exposure, natural zeolites show structural alterations which leads to a possibility to be used for different purposes in science and industry including building stones, concrete bricks and ceramic foam etc. The effect of heat treatment at $800^{\circ} \mathrm{C}$ with different treatment times of 30,60, 150 min of clinoptilolite rich zeolites from Gördes region of Turkey were investigated by Fourier Transform IR (FT-IR), solid state magic angle spinning nuclear magnetic resonance (MAS NMR), and X-ray diffraction (XRD) spectroscopic methods. The obtained spectroscopic results indicated that rather than a total collapse, severe structural distortions occur for the investigated samples.
\end{abstract}

Keywords: Zeolite, FT-IR, MAS NMR, XRD

\section{INTRODUCTION}

Zeolites, hydrated crystalline aliminosilicates having large voids and channels in the order of $3-10 \AA$ and a high $\mathrm{SiO}_{2} / \mathrm{Al}_{2} \mathrm{O}_{3}$ ratio have been widely used in the field of industry, agriculture, biomedical and environmental protection purposes [1-6]. Clinoptilolites structurally having HEU type zeolites show common HEU framework topology. They have high thermal stability and their $\mathrm{Si} / \mathrm{Al}$ ratio is bigger than 4 [7-12]. Knowledge of the thermal stability and structural changes of natural zeolites after heating allows obtaining useful information for possible applications in different fields e.g. civil engineering, catalysis and ceramic industry. It is possible to find many studies in the literature about the properties and possible applications of heat treated zeolites [13-18].

In order to follow the structural evolution of the synthetic or natural zeolites for various purposes, MAS NMR, FT-IR and XRD spectroscopic techniques are widely employed and they provide valuable information [19-21]. It was previously reported by Çağlar Duvarcı et al. that the structure of clinoptilolite from Gordes region was collapsed at $800^{\circ} \mathrm{C}$ [13]. In this work, it is aimed to investigate the structural behavior of the zeolite samples from the same region when the samples immediately exposed to $800^{\circ} \mathrm{C}$ with 30,60 and 150 min periods of time. In comparison with the untreated zeolite sample, the structural changes were monitored with ${ }^{29} \mathrm{Si},{ }^{27} \mathrm{Al},{ }^{1} \mathrm{H}$ MAS NMR, FT-IR and XRD spectroscopic techniques. Hereby, all the results obtained were discussed and explained in detail.

\section{EXPERIMENTAL}

\subsection{Materials and Methods}

Natural zeolite samples were obtained from Gördes region of Turkey. The samples were dry sieved using Retsch sieving equipment and ground to pass $63 \mu$ sieve. They were labelled as UZ (untreated zeolite), Z30 (treated $30 \mathrm{~min}$ at $800^{\circ} \mathrm{C}$ ), Z60 (treated $60 \mathrm{~min}$ at $800^{\circ} \mathrm{C}$ ) and $\mathrm{Z} 150$ (treated $150 \mathrm{~min}$ at $800^{\circ} \mathrm{C}$ ). The temperature of the oven was set to $800^{\circ} \mathrm{C}$ before the samples were put in it. Therefore, the structural behaviors of the samples after the sudden exposure to a high temperature $\left(800^{\circ} \mathrm{C}\right)$ were examined.

*Corresponding Author:ozguralver@eskisehir.edu.tr

Received: 30.01.2019 Published: 30.12.2019 


\subsection{Instrumentation}

Infrared spectra of the zeolite samples were recorded $\left(4000-400 \mathrm{~cm}^{-1}\right)$ with Bruker Tensor 27 spectrometer at a resolution of $4 \mathrm{~cm}^{-1}$ using $\mathrm{KBr}$ pellet technique. Solid state magic angle spinning (MAS) NMR spectra were recorded at $11.75 \mathrm{~T}$. All MAS NMR spectra were acquired on a JEOL ECZ 500R spectrometer. Resonance frequencies of ${ }^{1} \mathrm{H},{ }^{27} \mathrm{Al}$, and ${ }^{29} \mathrm{Si}$ were adjusted $500.15 \mathrm{MHz}, 130.32 \mathrm{MHz}$ and $99.36 \mathrm{MHz}$, respectively. All of the NMR spectra were acquired with $\Pi / 2$ single pulse and a relaxation delay time of $5 \mathrm{~s}$. Spectra observed with very short pulses which pulse width adjusted to $1 \mu \mathrm{s}$. Number of scan for ${ }^{1} \mathrm{H}$, ${ }^{27} \mathrm{Al}$ and ${ }^{29} \mathrm{Si}$ were adjusted as 256,3000 and 5000, respectively. $3.2 \mathrm{~mm}$ zirconium oxide rotors were used and they were spun at $10 \mathrm{kHz}$. Chemical shifts were quoted in ppm from external standard. Adamantane, aluminium nitrate and TMS were used as external standard for ${ }^{1} \mathrm{H},{ }^{27} \mathrm{Al}$ and ${ }^{29} \mathrm{Si}$, respectively. The XRD diffractograms were obtained with a Bruker instrument, using $\mathrm{CuK} \alpha$ radiation $(\lambda=1.54 \AA)$ at $40 \mathrm{kV}$ and $20 \mathrm{~mA}$, in the range $5-40^{\circ} 2 \theta$. The samples were scanned with a step of $0.02^{\circ} 2 \theta$.

\section{RESULTS AND DISCUSSIONS}

\subsection{IR Studies}

FT-IR spectra of the natural and heat treated samples are given in Figure 1. The band appeared at 3633 $\mathrm{cm}^{-1}$ is related to isolated or bridging O-H stretching vibrations [13, 22] and vibrations at 3459 and 1640 $\mathrm{cm}^{-1}$ refer to stretching and bending vibrations of water molecules [22]. The $1049 \mathrm{~cm}^{-1}$ band is due to antisymmetric stretching vibrations of internal $\mathrm{T}-\mathrm{O}$ bonds in $\mathrm{TO}_{4}$ tetrahedral structure where $\mathrm{T}$ stands for any atom in tetrahedral such as $\mathrm{Si}$ and $\mathrm{Al}[23,24]$.The band at $793 \mathrm{~cm}^{-1}$ could be attributed to symmetric O-T-O vibrations [22, 23, 25, 26]. The bands observed at 734 and $672 \mathrm{~cm}^{-1}$ refer to symmetric stretching vibrations of the free tetrahedral group $\mathrm{TO}_{4}[22,26]$.The vibrational band at $607 \mathrm{~cm}^{-1} \mathrm{can}$ be assigned as O-T-O bending vibrations [22, 26]. The bands at 521 and $468 \mathrm{~cm}^{-1}$ are due to "pore opening" vibrations and bending vibrations of $\mathrm{TO}_{4}[22,23,25]$.

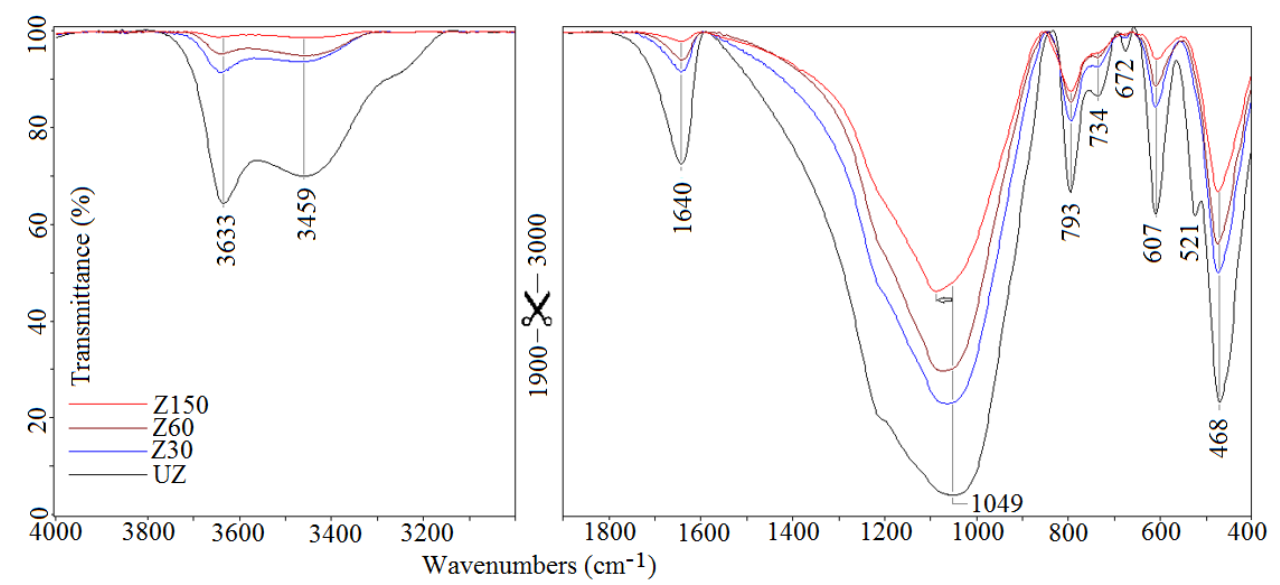

Figure 1. FT-IR spectra of treated (30, 60, $150 \mathrm{~min})$ and untreated (UZ) zeolite samples

\section{2. ${ }^{29} \mathrm{Si},{ }^{27} \mathrm{Al}$ and ${ }^{1} \mathrm{H}$ MAS NMR Studies}

${ }^{29} \mathrm{Si}$ and ${ }^{27} \mathrm{Al}$ MAS NMR spectra of the untreated and heat treated clinoptilolite samples were given in Figure 2 and Figure 3. In previously reported works with different origins of clinoptilolite samples, observed ${ }^{29} \mathrm{Si}$ peaks were assigned as $-92.30,-95 \mathrm{ppm}(\mathrm{Si}(0 \mathrm{Al})),-101.3499,-100 \mathrm{ppm}(\mathrm{Si}(1 \mathrm{Al}))$, $106.8226,-106 \mathrm{ppm}(\mathrm{Si}(2 \mathrm{Al}))$ and $-117.347,-111 \mathrm{ppm}(\mathrm{Si}(3 \mathrm{Al}))$, respectively where the numbers $(0$, 1,2 and 3 ) beside the $\mathrm{Al}$ indicate the number of aluminum atoms in the second coordination sphere [2729]. In this work, the mentioned values, since the peaks were broad enough, were found approximately as $-93,-99,-105$ and $-111 \mathrm{ppm}$, respectively. Since, Loewenstein's rule avoids the formation of Al-O$\mathrm{Al}$ bondings only possibility is the existence of $\mathrm{Al}(4 \mathrm{Si})$ units in the framework [30]. Therefore, ${ }^{27} \mathrm{Al}$ 
MAS NMR spectrum yielded a resonance peak at around $62 \mathrm{ppm}$ due to tetrahedrally coordinated aluminum as in agreement with the previously published works $[19,31]$. In addition to that, the very small broad peak at around $0 \mathrm{ppm}$ is due to octahedrally coordinated $\mathrm{AlO}_{6}$ units (Figure 3) [32]. ${ }^{1} \mathrm{H}$ MAS NMR spectra are given in Figure 4. Untreated sample shows an intense broad peak around 5 ppm due to water molecules. Spinning side bands are marked with asterisks. Peaks from bridging OH groups become visible as comparatively sharp peaks following the heat treatment as seen in Figure 4.

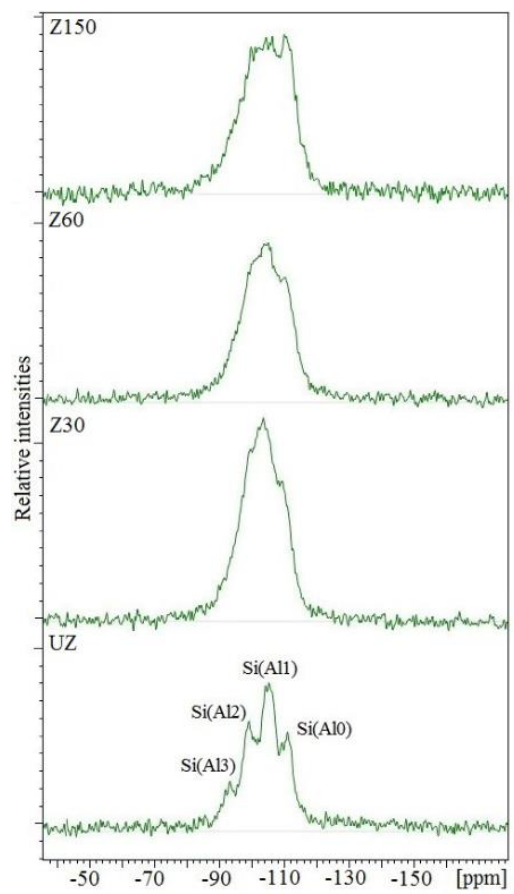

Figure 2. ${ }^{29}$ Si MAS NMR spectra of treated (30, 60, $\left.150 \mathrm{~min}\right)$ and untreated (UZ) zeolite samples.

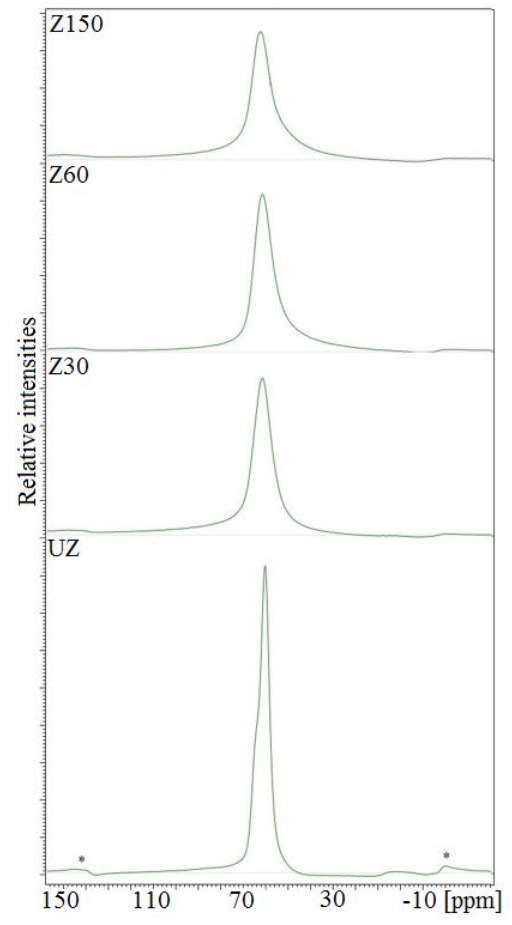

Figure 3. ${ }^{27} \mathrm{Al}$ MAS NMR spectra of treated (30, 60, $\left.150 \mathrm{~min}\right)$ and untreated (UZ) zeolite samples 


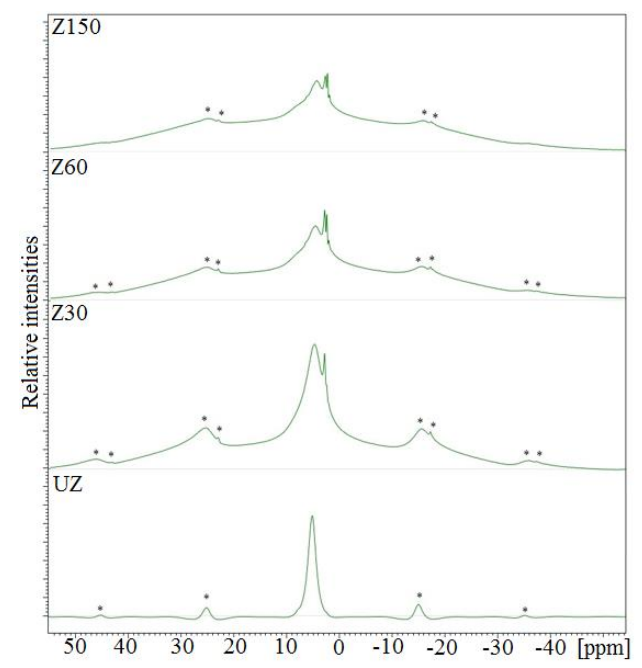

Figure 4. ${ }^{1} \mathrm{H}$ MAS NMR spectra of treated (30, 60, $\left.150 \mathrm{~min}\right)$ and untreated (UZ) zeolite samples.

\subsection{XRD Studies}

The X-ray diffraction patterns of clinoptilolite samples before and after thermal treatment at $800{ }^{\circ} \mathrm{C}$ for 30, 60 and 150 minutes are shown in Figure 5. Untreated clinoptilolite sample (UZ) exhibits good crystallinity and gives sharp peaks. X-ray diffraction analysis of the samples showed the positions of many characteristic peaks corresponding to the well crystallized clinoptilolite as indicated by the characteristic narrow and intense diffraction peaks at $2 \theta=9.83^{\circ}, 22.36^{\circ}, 26.00^{\circ}$ and $31.94^{\circ}[7,24,33$ 34]. The other peaks in same pattern belong to the some impurities in the clinoptilolite. The quantitative XRD analysis showed that the main mineral component of the UZ is clinoptilolite (80-85\%), together with minor amounts of Opal A (5-10\%) Opal-CT (5-6\%), smectite, mica-illite feldspar (1-3\%). The method given by Esenli and Sirkecioğlu [35] was used to determine the content of clinoptilolite sample. As the thermal treatment time increased for Z30 and Z60 samples (Figure 5), the intensities of the clinoptilolite peaks are decreased gradually. After heating of the clinoptilolite at $800{ }^{\circ} \mathrm{C}$ for 150 minutes, clinoptilolite peaks still appeared in the XRD pattern but their intensities decreased significantly indicating the considerable collapse of the crystal lattice. In addition, an appearance of increase of the background and increase in the broadness of peaks in the interval $20^{\circ}$ and $30^{\circ} 2 \theta$ (especially for Z150 sample) are due to the formation of amorphous structure. Similar changes after thermal treatment of clinoptilolite were reported by other researchers [13, 36-38].

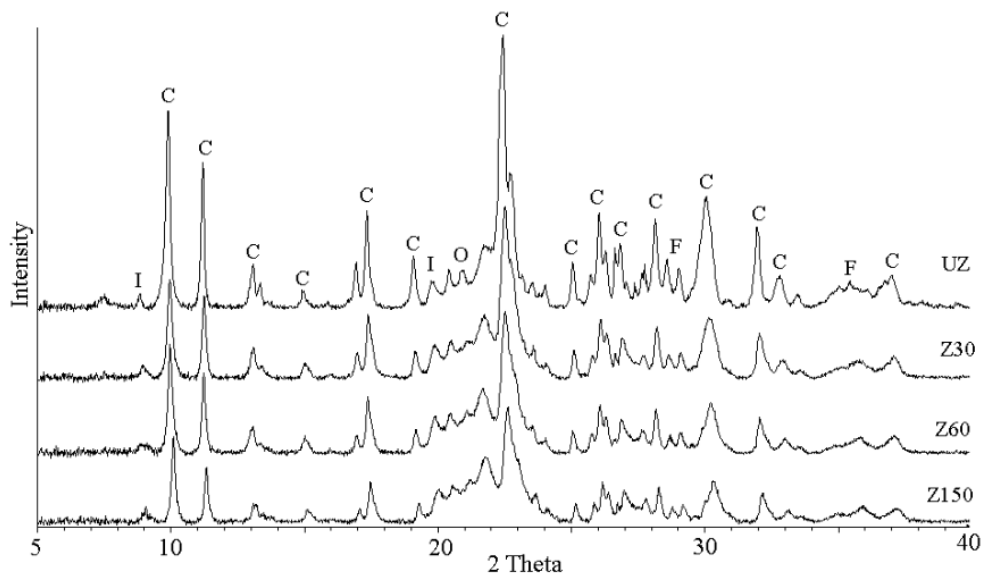

Figure 5. X-Ray diffraction pattern of untreated (UZ) and thermally treated (Z30, Z60 and Z150) clinoptilolite type zeolite samples (C, clinoptilolite; I, illite; O, opal-A; F, feldspar). 


\section{CONCLUSIONS}

In brief, following conclusions can be summed up:

i. Bridging stretching $\mathrm{OH}$ vibrations $\left(3633 \mathrm{~cm}^{-1}\right)$ and stretching and bending vibrations of water molecules ( 3459 and $1640 \mathrm{~cm}^{-1}$ ) reduced in intensity severely but still trace amount of them can be seen in the infrared spectrum after treatment at $800^{\circ} \mathrm{C}$ for $150 \mathrm{~min}$ (Figure 1). This fact was also verified by ${ }^{1} \mathrm{H}$ MAS NMR (Figure 4)

ii. The broad peak around $0 \mathrm{ppm}$ (Figure 3 ) due to six-coordinate aluminum occurred by the expulsion of A1 from the framework sites, disappeared just after the following heat exposure of $800^{\circ} \mathrm{C}$ for $30 \mathrm{~min}$ indicating the full destruction of this structure. The pore opening vibrational bands at $521 \mathrm{~cm}^{-1}$ disappeared as well indicating a distortion in the simultaneity of the pore dynamics (Figure 1).

iii. By analyzing ${ }^{27} \mathrm{Al}$ MAS NMR spectra (Figure 3), it was seen that the intensity of the band at around $60 \mathrm{ppm}$ belonging to tetrahedrally coordinated aluminum was reduced nearly to its half when compared to untreated clinoptilolite sample addressing the partial destruction of this structure but it is not still fully collapsed even after the heat treatment at $800{ }^{\circ} \mathrm{C}$ for $150 \mathrm{~min}$. This fact was also supported by the findings of XRD data (Figure 5).

iv. Si-O stretching vibrations appeared as the most shifted bands at around $36 \mathrm{~cm}^{-1}$ in the infrared spectrum (Figure 1) and ${ }^{29} \mathrm{Si}$ MAS NMR spectrum imply an agreement with this showing a severe broadening and distortion in the silicium resonance bands (Figure 2).

v. Finally, based on the spectroscopic results employed in this work, it can be concluded that a severe distortion was seen in the clinoptilolite structure of the investigated zeolite sample at $800^{\circ} \mathrm{C}$ with 150 min treatment time but full decomposition was not observed. Depending on the purpose, the examined zeolite samples can still be functional at $800^{\circ} \mathrm{C}$ for a period of 150 minutes.

\section{REFERENCES}

[1] Erdem E, Karapinar N, Donat R. The removal of heavy metal cations by natural zeolites. J. Colloid Interface Sci. 2004; 280: 309-314.

[2] Cabrera C, Gabaldon C, Marzal P. Sorption characteristics of heavy metal ions by a natural zeolite. J. Chem. Technol. Biotechnol. 2005; 80: 477-481.

[3] M. Danilczuk, K. Dlugopolska, T. Ruman, D. Pogocki. Molecular sieves in medicine, Mini Rev. Med. Chem. 2008; 8: 1407-1417.

[4] Andronikashvili T, Pagava K, Kurashvili T, Eprikashvili L. Possibility of application of natural zeolites for medicinal purposes. Bull. Georg. Natl. Acad. Sci. 2009; 3: 158-167.

[5] Otero Areán C, Turnes Palomino G, Llop Carayol MR, Pulido A, Rubeš M, Bludský O, Nachtigall P. Hydrogen adsorption on the zeolite Ca-A: DFT and FT-IR investigation. Chem. Phys. Lett. 2009; 477: 139-143.

[6] Deka A, Deka RC, Choudhury A. Adsorption of CO on gas phase and zeolite supported gold monomers: a computational study. Chem. Phys. Lett. 2010; 490: 184-188.

[7] Gottardi G, Galli E. Natural zeolites. Berlin: Springer, 1985. 
[8] Breck DW. Zeolite molecular sieves: structure, chemistry, and use. New York: Wiley, 1974.

[9] Breck DW. Potential uses of natural and synthetic zeolites in industry. In: Towsand RP, editor. The properties and application of zeolites, J Chem Soc (Lond), 1980.

[10] Tsitsishvili G, Andronikashvili T, Kirov G, Filizova L. Natural zeolites. New York, Ellis Horwood, 1992.

[11] Mumpton FA. Clinoptilolite redefined. Am .Min. 1960; 45: 351-69.

[12] Ackley MW, Giese RF, Yang RT. Clinoptilolite: an untapped potential for kinetic gas separations. Zeolites, 1992; 12: 780-787.

[13] Çağlar Duvarcı Ö, Akdeniz Y, Özmıhçı F, Ülkü S, Balköse D, Çiftçioğlu M. Thermal behaviour of a zeolitic tuff. Ceram. Int. 2007; 33: 795-801.

[14] Zhan Z, Ma N, Han H, Peng Y, Wang Z, Yan Y. Heat treatment for improving performance of inner-side zeolite NaA membranes on composite hollow fibers. J. Membr. Sci. 2015; 485: 94-102.

[15] Tran YT, Lee J, Kumar P, Kim KH, Lee SS. Natural zeolite and its application in concrete composite production. Compos. B. 2019; 165: 354-364.

[16] Burris LE, Maria CGJ. The effect of acid treatment on the reactivity of natural zeolites used as supplementary cementitious materials. Cement. Concrete Res. 2016; 79: 185-193.

[17] Yoldi M, Fuentes-Ordoňez EG, Korili SA, Gil A. Zeolite synthesis from industrial wastes. Micropor. Mesapor. Mat. 2019; 287: 183-191.

[18] Ahmad J, Häg MB. Effect of zeolite preheat treatment and membrane post heat treatment on the performance of polyvinyl acetate/zeolite 4A mixed matrix membrane. Sep. Purif. Technol. 2013; 115: $163-171$.

[19] Mozgawa W, Fojud Z, Handke M, Jurga S. MAS NMR and FTIR spectra of framework aluminosilicates. J. Mol. Struct. 2002; 614: 281-287.

[20] Costa DG, Capaz RB. Structural analysis of zeolite beta through periodic ab initio simulations of XRD and 29Si and 17O NMR spectra. J. Mol. Struct. 2015; 1097: 112-116.

[21] Kneller JM, Pietraß T, Ott KC, Labouriau A. Synthesis of dealuminated zeolites NaY and MOR and characterization by diverse methodologies: 27Al and 29Si MAS NMR, XRD, and temperature dependent 129Xe NMR. Micropor. Mesopor. Mat. 2003; 62: 121-131.

[22] Doula MK. Synthesis of a clinoptilolite-Fe system with high Cu sorption capacity. Chemosphere, 2007; 67: 731-740.

[23] Mansouri N, Rikhtegar N, Panahi HA, Atabi F, Shahraki BK. Porosity, characterization and structural properties of natural zeolite - clinoptilolite - as a sorbent. Environ. Prot. Eng. 2013; 39(1): 139-152.

[24] Korkuna O, Leboda R, Skubiszewska-Zięba J, Vrublevs'ka T, Gun'ko VM, Ryczkoeski J. Structural and physicochemical properties of natural zeolites: Clinoptilolite and mordenite. Micropor. Mesopor. Mat. 2006; 87: 243-254. 
[25] Faghihian H, Kabiri-Tadi M. Removal of zirconium from aqueous solution by modified clinoptilolite. J. Hazard. Mater. 2010; 178: 66-73.

[26] Tsyntsarski B, Petrova B, Budinova T, Petrov N, Sarbu A, Sandu T, Ferhat Yardım M, Sirkecioğlu A. Removal of detergents by zeolites and membranes. Bulg. Chem. Commun. 2014; 46(1): 157164.

[27] Kumbasa I, Özkar S. The study of clinoptilolite - rich tuffs from Bigadiç by NMR Technique. Turkish Geo. Bull. 1993; 36: 1-5.

[28] Rodriques-Fuentes G, de Ménorval LC, Reguera E, Chávez Rivas F. Solid state multinuclear NMR study of iron species in natural and modified clinoptilolite from Tasajera deposit (Cuba). Micropor. Mesopor. Mat. 2008; 111: 577-590.

[29] Riviera A, Farías T, Ruiz-Salvador AR, de Ménorval LC. Preliminary characterization of drug support systems based on natural clinoptilolite. Micropor. Mesopor. Mat. 2003; 61: 249-259.

[30] Loewenstein W. The distribution of aluminium in the tetrahedral of silicates and aluminates. Am. Mineral. 1954; 39: 92-96.

[31] Barras J, Klinowski J, McComb DW. 27Al and 29Si solid-state NMR studies of dealuminated mordenite. J. Chem. Soc. Faraday Trans. 1994; 90(24): 3719-3723.

[32] Hunger M, Brunner E. Characterization I-NMR Spectroscopy, in Molecular Sieves-Science and Technology, Springer, Berlin, 2004.

[33] Petrov OE. Cation Exchange in Clinoptilolite: An X-Ray Powder Diffraction Analysis. In Natural Zeolite'93: Occurrence, Properties, Use; Ming DW, Mumpton FA. Eds. International Committee on Natural Zeolites: Brockport, NY, 1995.

[34] Nezamzadeh-Ejhieh A, Moeinirad S. Heterogeneous photocatalytic degradation of furfural using NiS-clinoptilolite zeolite. Desalination, 2001; 273: 248-257.

[35] Esenli F, Sirkecioğlu A. The relationship between zeolite (heulandite-clinoptilolite) content and the ammonium-exchange capacity of pyrodastic rocks in Gordes, Turkey. Clay Miner. 2005; 40(4): $557-564$.

[36] Christidis GE, Moraetis D, Keheyan E, Akhalbedashvili L, Kekelidze N, Gevorkyan R, Yeritsyan $\mathrm{H}$, Sargsyan H. Chemical and thermal modification of natural HEU-type zeolitic materials from Armenia, Georgia and Greece. Appl. Clay Sci. 2003; 24: 79-91.

[37] Dimowa LT, Petrov SL, Shivachev BL. Natural and Zn exchanged clinoptilolite: in situ high temperature XRD study of structural behavior and cation positions. Bulg. Chem. Commun. 2013; 45(4): 466-473.

[38] Akkoca DB, Yılgın M, Ural M, Akçin H, Mergen A. Hydrothermal and thermal treatment of natural clinoptilolite zeolite from Bigadiç, Turkey: An experimental study. Geochem. Int. 2013; 51(7): 495-504. 